\title{
Transfection with trk Restores "Slow" NGF Binding, Efficient NGF Uptake, and Multiple NGF Responses to NGF-nonresponsive PC12 Cell Mutants
}

\author{
David M. Loeb and Lloyd A. Greene \\ Department of Palhology and Center for Neurobiology and Behavior, Columbia University, New York, New York 10032
}

NGF binds to and activates the protein tyrosine kinase gp 140prototr. Expression of this receptor is required for at least some responses to NGF. Three outstanding issues are addressed in the present work. First, we determined whether expression of gp 140protitr is required for all neuronal NGF responses. Second, we examined the role of gp140 prototk in NGF binding and internalization. Third, we addressed the utility of NGF-nonresponsive PC12nnr5 cells for study of the NGF mechanism. In contrast to wild-type PC12 cells, PC12nnr5 cells do not express endogenous gp 140 protork. We therefore asked whether they possess other defects that compromise NGF signaling pathways. To answer these questions, we transfected PC12nnr5 cells with a cDNA encoding full-length human gp $140^{\text {prototrk }}$ and isolated cell lines permanently expressing the receptor. Introduction of trk rescued all of the many and varied NGF responses assessed, including enhanced protein tyrosine phosphorylation, induction of immediate-early and neural-specific genes, neurite outgrowth and regeneration, maintenance of survival in serum-free medium, and stimulation of AChE activity. In contrast to PC12nnr5 cells, the trk-transfected lines also bind and internalize NGF with wild-type PC12 cell characteristics.

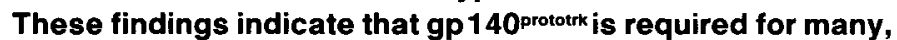
if not all, responses of neuronal cells to NGF and is necessary for proper NGF binding and internalization. Additionally, as no signaling defect other than the absence of trk expression was revealed in PC12nnr5 cells, this work supports the utility of this line for genetic dissection of the NGF mechanism of action.

IKey words: NGF, PC12 cells, PC12nnr cells, Trk, signal transduction, NGF receptor, NGF binding, NGF internalization, tyrosine kinase]

NGF mediates the differentiation and survival of discrete neuronal populations in both the CNS and PNS (Martinez et al., 1985; Levi-Montalcini, 1987; Barde, 1989; Cattaneo and McKay, 1990; Ruit et al., 1990). The rat pheochromocytoma cell

\footnotetext{
Received Nov. 19, 1992; accepted Jan. 26, 1993.

We thank Dr. Adrianna Rukenstein for help with tissue culture and with survival experiments, and Cynthia Nixon for help with AChE experiments. D.M.L. is a trainee of the MSTP program. This work was supported in part by grants from the March of Dimes Birth Defects Foundation and NIH-NINDS.

Correspondence should be addressed to Lloyd A. Greene, Department of $\mathrm{Pa}$ thology and Center for Neurobiology and Behavior, Columbia University, 630 West 168 th Street, New York, NY 10032
}

Copyright (C) 1993 Society for Neuroscience $0270-6474 / 93 / 132919-11 \$ 05.00 / 0$ line PC12 (Greene and Tischler, 1976) has been used extensively as an in vitro model to study NGF signaling (Levi et al., 1988). Two distinct NGF receptors, designated p75 and gp140 protork (Trk), have been identified, and cDNAs encoding these have been cloned (Chao et al., 1986; Radeke et al., 1987; MartinZanca et al., 1989). The discovery that NGF binds to and stimulates the tyrosine kinase activity of the gp 140 prototrk (Bothwell, 1991; Kaplan et al., $1991 \mathrm{a}, \mathrm{b}$; Klein et al., 1991) has focused attention on its role in NGF signal transduction. Transfection experiments have demonstrated that gp $140^{\text {prototrk }}$ mediates NGFstimulated fibroblast transformation (Cordon-Cardo et al., 1991) and oocyte maturation (Nebreda et al., 1991) as well as neurite outgrowth and cell survival (Loeb et al., 1991). The latter results were achieved by transfection of mutant PC12-derived cell lines (designated PC12nnr) selected for their inability to respond to NGF (Green et al., 1986). These cells express p75 hut not gp140 prototrk (Green and Greene, 1986; Loeb et al., 1991).

The present study addresses several outstanding issues concerning NGF receptors and PC12nnr cells. First is the question of whether expression of gp 140 prototrk mediates all neuronal responses to NGF. Our initial study with transiently transfected cells permitted only a few responses to be assessed (Loeb et al., 1991). The $t r k$ family is diverse (Bothwell, 1991), and multiple forms of some family members have been detected (Klein et al., 1990; Middlemas et al., 1991). It is not inconceivable that trk isoforms each mediate only a subset of responses, and that activation of multiple different Trk receptors is required for complete responsiveness. Furthermore, although the role of p75 is not entirely clear, it has been postulated that this receptor alone can mediate certain responses to NGF (Seilheimer and Schachner, 1987; Represa et al., 1991; Saad et al., 1991).

A second issue concerns the role of gp $140^{\text {prototr }}$ in NGF binding and uptake. Two classes of NGF binding sites have been detected on PC12 and other NGF-responsive cells (Sutter et al., 1979; Landreth and Shooter, 1980; Meakin and Shooter, 1992). There is disagreement regarding the definition of these classes, but it is clear that one class is distinguished by a "slow" rate of NGF dissociation, while the other undergoes "fast" dissociation (Schechter and Bothwell, 1981). PC12nnr cells appear to express predominantly "fast" receptors, suggesting that they lack an essential component for "slow" binding (Green et al., 1986). When expressed in fibroblasts, gp 140 prototk appears to show properties of "slow" NGF receptors (Meakin et al., 1992), suggesting that introduction of this molecule into the neuronal background of PC12nnr cells would restore "slow" NGF binding. In addition to surface binding, another important component of the NGF mechanism appears to be uptake and retrograde 
transport of the factor by neurons (Calissano and Shelanski, 1980; Levi et al., 1980; Korsching and Thoenen, 1983a; Palmetier et al., 1984; Johnson et al., 1987). PC12 cells efficiently internalize $\mathrm{NGF}$, while $\mathrm{PC} 12 \mathrm{nnr}$ cells show greatly reduced NGF uptake (Green et al., 1986). These observations raise the possibility that gp $140^{\text {prototr }}$ may be essential for efficient NGF internalization.

A third issue is the utility of PC12nnr cells for studying the mechanism of NGF signaling. If the only defect in the NGF signaling pathway in PC12nnr cells is the absence of Trk expression, then they may be used genetically to dissect functional domains of this receptor in a neuronal background. However, if the cells contain additional mutations, such analysis would be compromised.

To address these questions, we have established PC.12nnr cell lines that have been permanently transfected with human gp 140 prototr. These lines have been screened for a wide variety of NGF responses and signaling pathways and for their abilities to bind and internalize NGF.

\section{Materials and Methods}

Cells and growth factors. PC12 cells were grown on collagen-coated tissue culture dishes in RPMI 1640 medium supplemented with $10 \%$ heat-inactivated horse serum and $5 \%$ fetal bovine serum as previously described (Greene and Tischler, 1976). NGF was purificd from male mouse submaxillary glands as previously described (Mobley et al., 1976). For assay of neurite outgrowth, cultures were maintained in RPMI 1640 medium with $1 \%$ heat-inactivated horse serum and $100 \mathrm{ng} / \mathrm{ml} \mathrm{NGF}$. Regeneration assays were performed as described (Greene, 1977). For each culture condition, 300 randomly chosen individual cells were scored under phase-contrast optics. A neurite was defined as a cellular process greater than two cell body diameters in length. Cells assayed for survival in serum-free medium were cultured in RPMI 1640 medium without supplement.

Transfection and selection of permanently transfected clones. PC12nnr5 cells were transfected with pDM 115 (Kaplan et al., 1991a) by electroporation as previously described (Greene et al., 1991). Briefly, cells from a confluent $150 \mathrm{~mm}$ dish were washed free of serum and electroporated with $40 \mu \mathrm{g}$ of plasmid DNA using a Bethesda Research Labs (Gaithersburg, MD) Cell-Porator electroporation apparatus. After a $30 \mathrm{~min}$ recovery on ice, the cells were plated on two $100 \mathrm{~mm}$ dishes and incubated with complete medium. Selection was initiated $7 \mathrm{~d}$ after transfection by including $500 \mu \mathrm{g} / \mathrm{ml}$ geneticin in the culture medium. After approximately 4-6 weeks, surviving colonies were picked, expanded, and screened for responsiveness to NGF.

Immunoprecipitation, Western blotting, and kinase assays. Routinely, immunoprecipitations were performed using confluent $100 \mathrm{~mm}$ dishes of cells. Cultures were treated with $100 \mathrm{ng} / \mathrm{ml} \mathrm{NGF}$ for $5 \mathrm{~min}$ unless otherwise stated. Cultures were harvested in lysis buffer (LB) as previously described (Loeb et al., 1992) and extracted on ice for at least 5 min. After centrifugation at $190,000 \times g$ for $15 \mathrm{~min}$ at $4^{\circ} \mathrm{C}$, supernatants were normalized for protein concentration by a dye-binding assay (Bethesda Research Labs, Gaithersburg, MD) using bovine serum albumin (BSA) as a standard. Lysates were immunoprecipitated with anti-Trk antiserum 203 (Hempstead et al., 1992) at 1:200 for $2 \mathrm{hr}$ at $4^{\circ} \mathrm{C}$. Protein A-Sepharose (Pharmacia, Piscataway, NJ) prepared according to Upstate Biotechnology (Lake Placid, NY) was added for a further hour. Pellets were collected by centrifugation and washed with TNTG (10 $\mathrm{mm}$ Tris, pH 7.4, $150 \mathrm{~mm} \mathrm{NaCl}, 0.1 \%$ Triton $\mathrm{X}-100$, and $5 \%$ glycerol), boiled in Laemmli sample buffer, and subjected to SDS-PAGE (Laemmli, 1970).

Immunoprecipitates used for kinase assays were not boiled. Instead this material was incubated in kinase buffer (50 mM Tris, pH 7.5, 10 mM $\mathrm{MnCl}_{2}, 5 \mathrm{~mm} \mathrm{MgCl}_{2}, 5 \mu \mathrm{M}$ ATP, $5 \mu \mathrm{Ci}\left[\gamma^{-32} \mathrm{P}\right] \mathrm{ATP}$, and $15 \mu \mathrm{g}$ myelin basic protein [MBP]) for $10 \mathrm{~min}$ at $37^{\circ} \mathrm{C}$. Reactions were stopped by adding $4 \times$ sample buffer (Laemmli, 1970) and boiling. Results were quantified by subjecting the reaction mixture to SDS-PAGE and autoradiography.

Material for Western blotting without prior immunoprecipitation was prepared from untreated or NGF-treated cell cultures harvested in LB without detergent. After homogenization in a glass homogenizer, cellular material was centrifuged as described above, and the supernatant mixed with $4 \times$ sample buffer (Laemmli, 1970), boiled, and subjected to SDSPAGE.

Protein was transferred to nitrocellulose (Schleicher and Schuell, Keene, $\mathrm{NH}$ ) by electroblotting (Loeb et al., 1992). Nonspecific binding sites on nitrocellulose membranes were blocked with 3\% BSA in PBS for $2 \mathrm{hr}$ at room temperature. Membranes were then incubated with the appropriate antiserum diluted as indicated in the text in 3\% BSA in PBS overnight at $4^{\circ} \mathrm{C}$. Membranes were washed with $0.2 \%$ NP-40 in PBS for $1 \mathrm{hr}$, and immunoreactive bands were revealed with ${ }^{125}$ I-Protein A (ICN, Irvine, CA) and autoradiography using Kodak X-AR film. Results were quantified by scanning densitometry using an Apple OneScan driven by ororo (Light Suurce, Inc., Greenbrae, CA) and image (version 1.43, National Institutes of Health) software run on an Apple Quadra model 700 computer.

Isolation of RNA and Northern blotting. RNA was prepared from cultured cells by the method of Chomczynski and Sacchi (1987). RNA was separated by electrophoresis through $1 \%$ agarose gels as previously described (Loeb et al., 1991). After transfer to nitrocellulose, blots were incubated with probes labeled with $\left[\alpha-{ }^{32} \mathrm{P}\right] \mathrm{dCTP}$ using a random primed labeling kit (Boehringer Mannheim, Indianapolis, IN). RNA species were then detected by autoradiography. Results were quantified by scanning densitometry as described above.

NGF labeling and binding studies. NGF was labeled by lactoperoxidase according to the protocol of Vale and Shooter (1985). Unincorporated iodine was separated from labeled NGF using a disposable gel filtration column (Speedy Column, Pierce, Rockford, IL) followed by centrifugation through a Centriflo CF50 filter (Amicon, Danvers, MA) as suggested by Vale and Shooter (1985). NGF was labeled to a specific activity of $14 \mathrm{cpm} / \mathrm{pg}$ and used within 2 weeks of labeling.

Dissociation studies were performed on confluent $35 \mathrm{~mm}$ dishes of cells. Cells were incubated with $5.55 \mathrm{ng} / \mathrm{ml}(\sim 210 \mathrm{pM}) \mathrm{NGF}$ in RPMI 1640 medium with $1 \%$ heat-inactivated horse serum for $3 \mathrm{~min}$ at $37^{\circ} \mathrm{C}$. After transfer to ice, cultures were washed rapidly six times with icecold PBS and incubated with $1 \mu \mathrm{g} / \mathrm{ml}$ unlabeled NGF in HEPES $(N-[2-$ hydroxyethyl] piperazine- $N^{\prime}$-[2-ethanesulfonic acid])-buffered KrebsRinger solution (pH 7.4) with $1 \%$ horse serum. At various times cultures were assayed for released (soluble) ${ }^{125} \mathrm{I}-\mathrm{NGF}$, surface-bound (as determined by acid stripping; Bernd and Greene, 1984) ${ }^{125}$ I-NGF, and internalized ${ }^{125}$ I-NGF (that which was not removed by acid treatment). Cells were acid stripped for $5 \mathrm{~min}$ on ice by incubation with $0.2 \mathrm{~N}$ acetic acid containing $0.5 \mathrm{M} \mathrm{NaCl}$. This protocol has been shown to completely remove surface-bound NGF (Bernd and Greene, 1984).

NGF uptake was measured by incubating $35 \mathrm{~mm}$ dishes of cells with $5.55 \mathrm{ng} / \mathrm{ml}{ }^{125}$ I-NGF in RPMI 1640 with $1 \%$ horse serum for various times at $37^{\circ} \mathrm{C}$. Cells were transferred to ice and rapidly washed six times with ice-cold PBS, and surface and internalized ${ }^{125}$ I-NGF were determined as described above. All results were quantified using a Clinigamma 1272 gamma counter (Pharmacia-LKB, Gaithersburg, MD).

Acetylcholinesterase assay. Acetylcholinesterase activity was determined as previously described (Greene and Rukenstein, 1981).

\section{Results}

Expression of gp 140 protork in stably transfected PC12nnr5 cells. PC12nnr5 cells (Green et al., 1986) were transfected by electroporation with a plasmid (pDM115; Kaplan et al., 1991a) containing the full-length cDNA encoding human gp140 prototr and the gene for neomycin resistance, both under the control of a retroviral LTR. After selection with geneticin, colonies were isolated, expanded, and examined for trk expression. Since previous work showed that transient expression of trk renders PC12nnr5 cells capable of NGF-promoted neurite outgrowth (Loeb et al., 1991), this response was used as an initial screen. Of 30 colonies isolated, nine (30\%) expressed $t r k$ as judged by their ability to grow neurites in response to NGF. Of these, the three with morphologies most closely resembling that of PC12nnr5 and PC12 cells (in the absence and presence of NGF; designated nnr5 18 , nnr519, and nnr5T14) were chosen for further evaluation (Fig. 1). One line derived from the transfection that was resistant to gencticin but did not grow ncurites (designated nnr5T1) was carried as a control. 
A

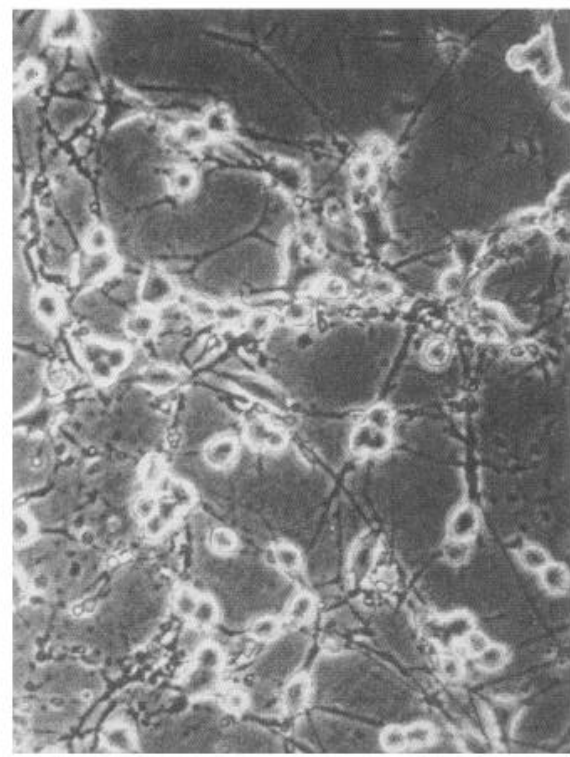

B

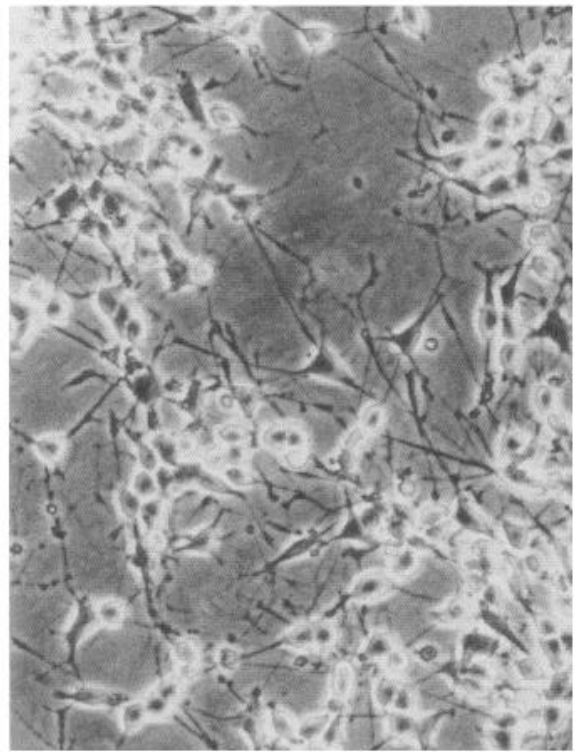

C

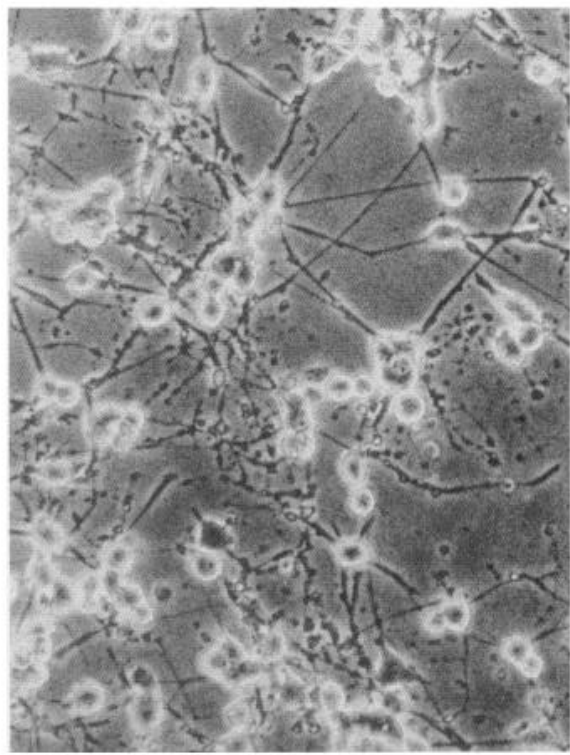

Figure 1. Morphological response of trk-transfected PC12nnr5 cell lines to NGF: nnr5T8 $(A)$, nnr5T9 $(B)$, and nnr5T14 (C) cells treated for $7 \mathrm{~d}$ with $100 \mathrm{ng} / \mathrm{ml} \mathrm{NGF}$. Photographs were taken under phase-contrast optics.

To confirm expression of the human trk gene and gp $140^{\text {protork }}$ in the geneticin-resistant cells, Northern and Western blot analyses were performed. Northern blot analysis using a $t r k$-specific probe (Kaplan et al., 1991a) revealed that -like PC12 cellsnnr5T8, nnr5T9, and nnr5T14 cells express trk mRNA (Fig. $2 A$ ). The trk mRNA expressed by the transfected cell lines migrates more slowly than the corresponding mRNA from PC12 cells, consistent with expression of the exogenous gene and not with reactivation of endogenous trk (Fig. $2 A$ ). PC12nnr5 and nnr5T1 cells do not express detectable trk message, consistent with their inability to grow neurites in response to NGF (Fig. $2 A$ ). All three $t r k$-expressing transfectants overexpress the transgene relative to wild-type $\mathrm{PC} 12$ cells. Densitometric analysis of the Northern blot shown in Figure $2 A$ indicated that the range of trk overexpression varies from about 10-(nnr5T14) to 20fold (nnr5T9). Similar results were obtained in additional Northern blot experiments.

To detect gp 140 protork expression, $\mathrm{PC} 12$, nnr5T8, nnr5T9, and nnr5T14 cells were lysed in a Triton X-100-containing buffer, and the solubilized material was immunoprecipitated with antiTrk antiserum 203 (Hempstead et al., 1992). SDS-PAGE of the immunoprecipitates, followed by Western blotting with the same antiserum, revealed that all four lines express gp140 protork (Fig. $2 B$ ), and that, consistent with the Northern blot results, the transfected lines overexpress the protein relative to $\mathrm{PC} 12$ cells. No gp $140^{\text {prototrk }}$ expression was detected in nnr5T1 or PC12nnr5 immunoprecipitates (data not shown). Densitometric analysis of the Western blot shown in Figure $2 B$ indicated that the range of gp 140 protorrk overexpression varied from about 6- (nnr5T9) to 10 -fold (nnr5T8). In addition, immunoprecipitation of lysates from untreated and NGF-treated (100 ng/ml for $5 \mathrm{~min}) \mathrm{PC} 12$, nnr5T8, and nnr5T14 cells with anti-Trk antiserum 203 followed by SDS-PAGE and Western blotting with anti-phosphotyrosine revealed an NGF-dependent tyrosine phosphorylation of gp140 protork in each cell line (Fig. $2 C$ ). Similar results were obtained with nnr5T9 cells (data not shown). In contrast to the other lines, nnr5T8 cells exhibit a low level of tyrosine-phosphorylated gp $140^{\text {prototrk }}$ in the absence of NGF (Fig. 2C). This presumably reflects ligand-independent receptor activation caused by the overexpression of this protein. However, even though nnr5T8 cells contain a basal level of tyrosine-phosphorylated (and presumably active) gp140 protork, NGF is still required for these cells to elaborate neurites.

Expression of gp 140 porotork rescues wild-type NGF binding and uptake characteristics. To test the effect of Trk expression on binding and uptake of NGF by PC12nnr5 transfectants, the rate of dissociation of radiolabeled NGF from the cell surface and the rate of factor internalization were examined. For dissociation studies, $\mathrm{PC} 12$, $\mathrm{PC} 12 \mathrm{nnr} 5$, nnr5T1, and nnr5T14 cells were incubated with $5.55 \mathrm{ng} / \mathrm{ml}(\sim 210 \mathrm{pm})$ iodinated NGF for $3 \mathrm{~min}$ at $37^{\circ} \mathrm{C}$ to allow cell surface binding with minimal internalization. Cells were then shifted to $0^{\circ} \mathrm{C}$, the labeled NGF rapidly washed away, and the medium replaced with one containing 1 $\mu \mathrm{g} / \mathrm{ml}$ unlabeled NGF. As described in Materials and Methods, labeled NGF in the medium, on the cell surface, and inside the cell was measured at various times after washout and chase. During the 3 min binding period, the cell lines bound different amounts of labeled NGF. While PC12nnr5 and nnr5T1 cells bound approximately $60-90 \mathrm{fmol} \mathrm{NGF} / \mathrm{mg}$ cell protein this time, PC12 and nnr5T14 cells bound approximately threefold more. This is consistent with the expression of more receptors

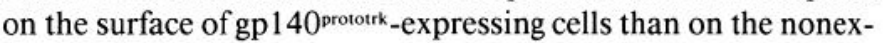
pressing cells. Previous work also demonstrated fewer binding sites on the surface of PC12nnr5 cells as compared with parental PC12 cells (Green et al., 1986). In agreement with published results (Schechter and Bothwell, 1981; Eveleth and Bradshaw, 1988), the cell lines exhibited biphasic NGF dissociation kinetics. PC12 and nnr5T14 cells had relatively small amounts of rapidly dissociating NGF (losing $10-20 \%$ of the total surfacebound NGF after $10 \mathrm{~min}$ ) while the PC12nnr5 and nnr5T1 cells 
A

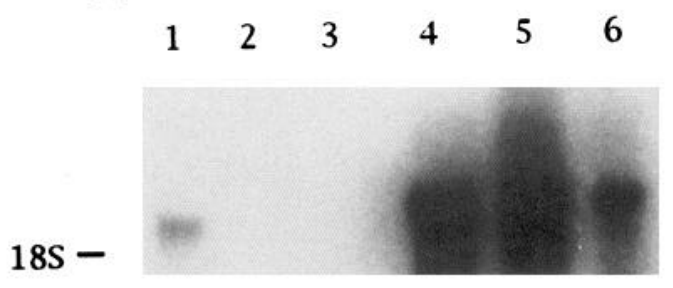

B

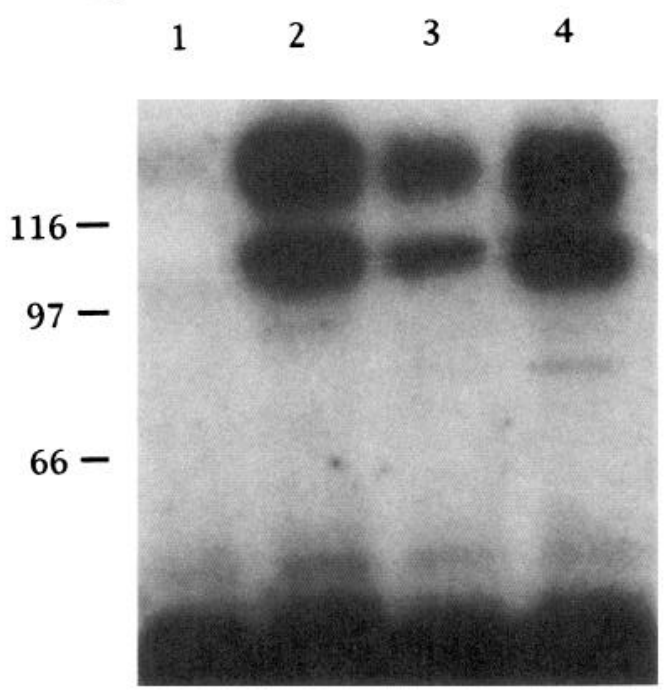

C

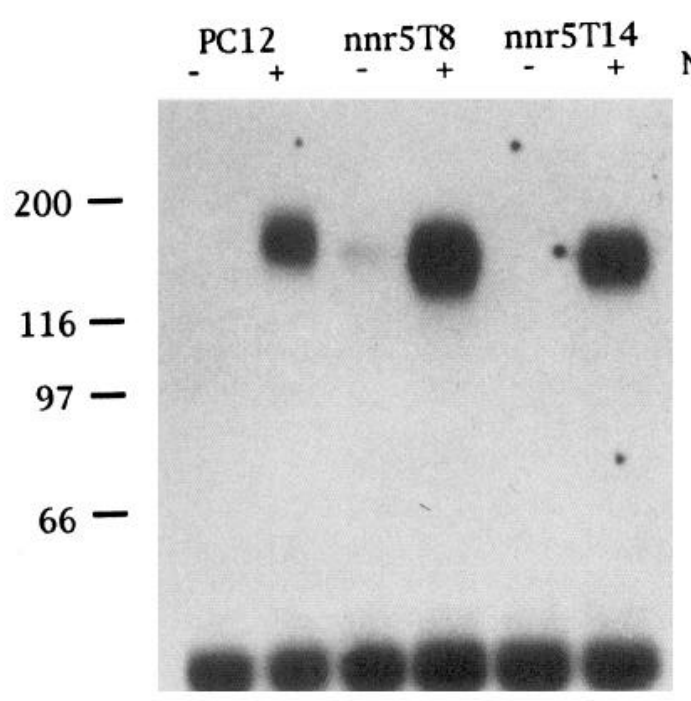

Figure 2. Expression of $t r k$ mRNA and functional gp $140^{\text {protork }}$ in permanently transfected cell lines. $A$, Total cellular RNA was isolated from PC12 (lane 1), PC12nnr5 (lane 2), nnr5T1 (lane 3), nnr5T8 (lane 4), nnr5T9 (lane 5), and nnr5T14 (lane 6) cells and subjected to Northern blot analysis ( $20 \mu \mathrm{g} /$ lane) with a trk-specific probe (pDM97; Kaplan et al., 1991a). Equal loading of RNA in each lane was verified by ethidium bromide staining. The position of the $18 \mathrm{~S}$ rRNA is indicated. $B$, Trk protein was immunoprecipitated from lysates of PC12 (lane 1), nnr5T8 lost from $45-65 \%$ of their surface-bound NGF in the same time period (Fig. $3 A$ ).

Substrate-attached PC12 cells show a marked time-dependent intracellular accumulation of NGF, reflected by an increasing ratio of internal to surface-bound factor. In contrast, PC12nnr5 cells do not show a similar accumulation or high internal-tosurface (I/S) ratio (Green et al., 1986). To examine the role of gp 140 prototrk expression in this phenomenon, internalization of NGF by PC12, PC12nnr5, nnr5T1, and nnr5T14 cells was examined. After incubation for 3 or $60 \mathrm{~min}$ at $37^{\circ} \mathrm{C}$ with $5.55 \mathrm{ng} /$ $\mathrm{ml}(\sim 210 \mathrm{pM})$ radiolabeled NGF, cell surface and internalized NGF was measured. PC12nnr5 and nnr5T1 cells had an I/S ratio of approximately 1 after $60 \mathrm{~min}$, while PC12 cells had a ratio of 2-3 and nnr5T14 cells had a ratio of approximately 4 (Fig. $3 B$ ). The amounts of ligand bound to the surfaces of the different cell lines after $60 \mathrm{~min}$ were approximately equivalent (Fig. 3B).

Expression of gp $140^{\text {protork }}$ rescues rapid tyrosine phosphorylations and association with cytoplasmic serine/threonine kinases. Among the earliest responses of $\mathrm{PC} 12$ cells to NGF is the rapid tyrosine phosphorylation of cytoplasmic proteins (Maher, 1988, 1989). To determine if this response is rescued in PC12nnr5 cells by transfection with trk, PC12 and nnr5T14 cells, untreated or treated with $100 \mathrm{ng} / \mathrm{ml} \mathrm{NGF}$ for $5 \mathrm{~min}$, were homogenized in an isotonic buffer, and soluble proteins were subjected to SDS-PAGE followed by Western blotting with an anti-phosphotyrosine antibody. The major NGF-stimulated tyrosine phosphorylations are bands of 44 and $42 \mathrm{kDa}$ (probably representing ERK1 and ERK2; Boulton et al., 1991) and approximately $100 \mathrm{kDa}$ (Fig. $4 A$ ). All of these were seen in both the PC12 cell lysates and the nnr5T14 lysates. Similar results were obtained with nnr5T8 cells (data not shown). No NGFdependent tyrosine phosphorylation was seen with PC12nnr5 cells (data not shown).

NGF induces association between gp 140 prototrk and at least two different serine/threonine kinases in PC12 cells, ERK1 (Loeb et al., 1992), and a non-ERK kinase activity (Volonté et al., 1993). To determine if these complexes are formed in PC12nnr5 cells transfected with $t r k$, thus strengthening the hypothesis that the sole defect underlying the lack of NGF responsiveness in these cells is the absence of $t r k$ expression, their presence in nnr5T9 cells was assessed. Untreated cells and cells treated for $5 \mathrm{~min}$ with $100 \mathrm{ng} / \mathrm{ml} \mathrm{NGF}$ were lysed in a Triton-containing buffer, and the lysates were immunoprecipitated with antiserum 43, which recognizes gp 140 prototrk (Klein et al., 1991a). Precipitated material was subjected to Western blotting using antiserum X837, which recognizes ERK1 and ERK2 (Boulton and Cobb, 1991). An NGF-dependent association between gp 140 ${ }^{\text {prototrk }}$ and ERK1 was detected in PC12 cells and in nnr5T9 cells (Fig. $4 B$ ). No

(lane 2), nnr5T9 (lane 3), and nnr5T14 (lane 4) cells with anti-Trk antiserum 203. After SDS-PAGE, proteins were subjected to Western blotting analysis with the same antiserum. The relative migration of molecular weight standards $\left(M_{r} \times 10^{-3}\right)$ is indicated. The lower band of each doublet in lanes 2-4 is partially glycosylated gp 140 prototrk (MartinZanca et al., 1989). C, PCl2, nnr5T8, and nnr5T14 cells, treated with $(+)$ or without $(-) 100 \mathrm{ng} / \mathrm{ml} \mathrm{NGF}$ for $5 \mathrm{~min}$, were lysed and subjected to immunoprecipitation with anti-Trk antiserum 203. After SDS-PAGE, proteins were subjected to Western blotting analysis with anti-phosphotyrosine. Relative migration of molecular weight standards $\left(M_{r} \times\right.$ $\left.10^{-3}\right)$ is indicated. 
such complex was detected in PC12nnr5 cells or in nnr5T1 cells (data not shown) regardless of NGF treatment.

NGF also stimulates a serine/threonine kinase activity that is associated with gp 140 protork, that uses MBP as an in vitro substrate, but that is not ERK1 (Volonté et al., 1993). To determine if this association and activation also occur in trktransfected PC12nnr5 cells, PC12, PC12nnr5, nnr5T1, and nnr5T9 cells, untreated or treated with $100 \mathrm{ng} / \mathrm{ml} \mathrm{NGF}$ for 5 min, were lysed in a Triton-containing buffer, immunoprecipitated with anti-Trk antiserum 443 (which does not precipitate the gp140 protork/ERK1 complex; Loeb et al., 1992), and assayed for protein kinase activity using MBP as a substrate. The basal level of kinase activity toward MBP is higher in anti-Trk immunoprecipitates derived from PC12 and nnr5T9 cells than in anti-Trk immunoprecipitates from PC12nnr5 or nnr5T1 cells (Fig. 4C). Additionally, NGF treatment augmented this protein kinase activity in the immunoprecipitates from $\mathrm{PC} 12$ and nnr5T9 cells but not in the material immunoprecipitated from PC12nnr5 or nnr5T1 cells (Fig. $4 C$ ).

Expression of gp 140 protork rescues NGF effects on gene expression and purine analog-defined signaling pathways. Through the use of purine analog protein kinase inhibitors (Zinn et al., 1988; Volonté et al., 1989), three divergent NGF signaling pathways within PC12 cells have been identified (Volonté et al., 1989; Batistatou et al., 1992). This identification is based in part on the ability of these compounds to inhibit differentially the induction of immediate-early genes by NGF (Batistatou et al., 1992). To determine if all three of these signaling pathways are functional in $\mathrm{PCl} 2 \mathrm{nnr} 5$ cells transfected with $t r k$, induction of genes representative of each pathway were assessed, including c-fos (Greenberg et al., 1985; Milbrandt, 1986), c-jun (Wu et al., 1989), TISI (also referred to as NGF-IB; Kujubu et al., 1987; Milbrandt, 1988), and TIS8 (also referred to as NGF-IA; Kujubu et al., 1987; Milbrandt, 1987). Total cellular RNA was isolated from $\mathrm{PC} 12$ and nnr5T14 cells treated for various times with $100 \mathrm{ng} / \mathrm{ml}$ NGF, and Northern blot analyses using probes for these genes were performed. All four genes were induced by NGF in both PC12 and nnr5T14 cells with similar rapid and transient kinetics (an example is shown in Fig. $5 A$ ). Induction of these genes by NGF is not detected in PC12nnr5 cells (Altin et al., 1991). The extent of induction of the genes differed somewhat between PC12 and nnr5T14 cells, but the significance of this finding is not clear.

Besides stimulating the expression of immediate-early genes, NGF induces the later expression of several additional genes in PC1 2 cells. Examples include the protease transin (Machida et al., 1989), the intermediatc filament protcin peripherin (Lconard et al., 1988), the microtubule-associated protein MAP1.2/1b/5 (Lewis et al., 1986), the cell surface NILE/L1 glycoprotein (Salton et al., 1983; Sajovic et al., 1986), and the p75 NGF receptor (Miller et al., 1991). Total RNA was isolated from PC12, PC12nnr5, nnr5T1, and nnr5T 14 cells, untreated or treated with $100 \mathrm{ng} / \mathrm{ml} \mathrm{NGF}$ for 3 or $7 \mathrm{~d}$. Northern blot analysis of these samples revealed an NGF-dependent expression of transin mRNA in PC12 and nnr5T14 cells but not in PC12nnr5 or nnr5T1 cells (Fig. 5B). All four cell lines express basal levels of mRNA encoding NILE/L1 glycoprotein, MAP1.2/1b/5, p75, and peripherin in the absence of NGF; however, NGF enhances the expression of each of these genes in PC12 and nnr5T14 cells, but not in PC12nnr5 or nnr5T1 cells (Table 1). Another gene whose expression is augmented by NGF in $\mathrm{PC} 12$ cells is thymosin $\beta 4$ (Leonard et al., 1987). However, unlike the other late
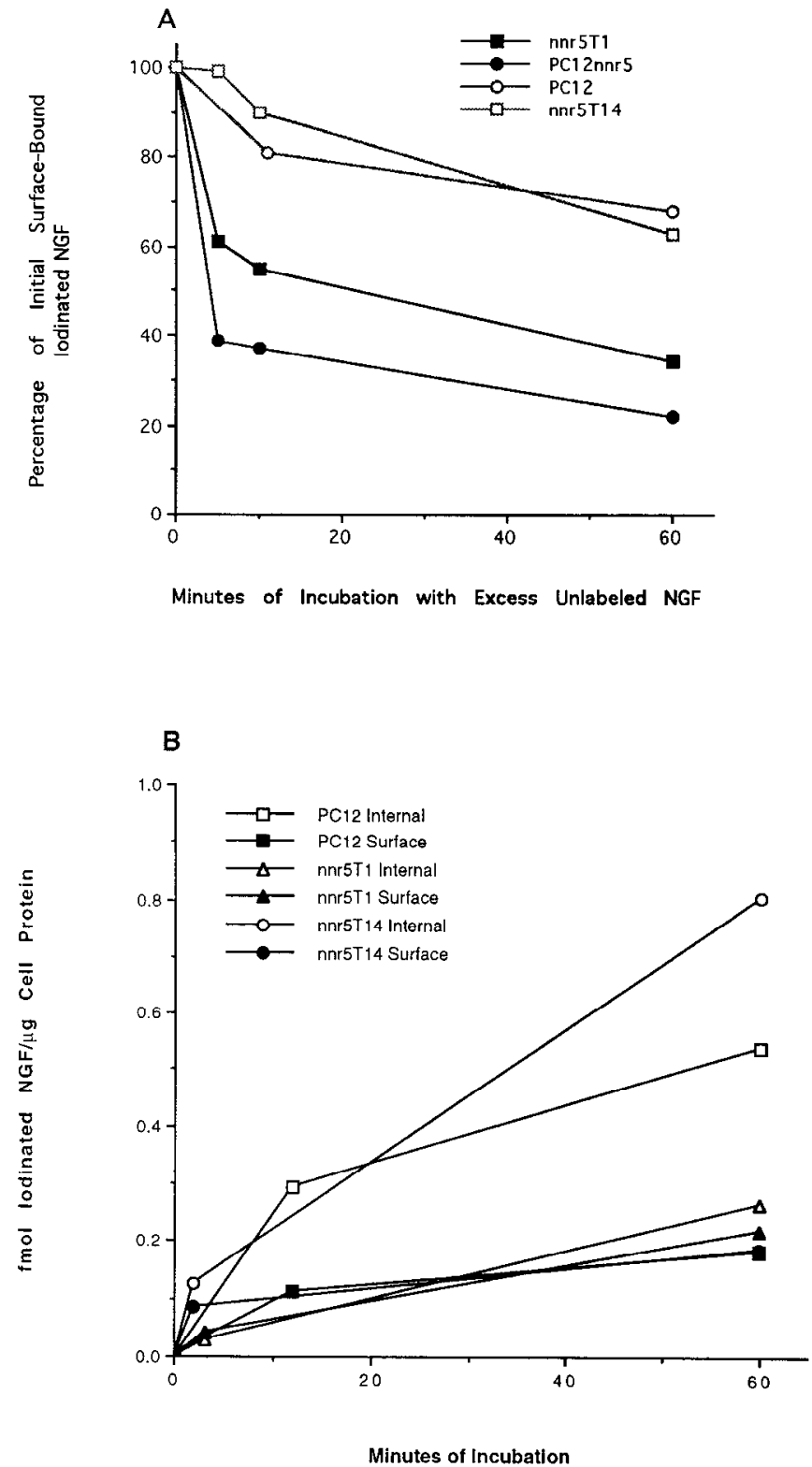

Figure 3. NGF binding, dissociation, and internalization. $A$, Relative rate of dissociation of ${ }^{125}$ I-NGF from the surfaces of PC12, PC12nnr5, nnr5T1, and nnr5T14 cells, assayed as described in Materials and Methods. Briefly, replicate cultures were incubated with $\sim 210$ pM ${ }^{125}$ I-NGF for $3 \mathrm{~min}$ at $37^{\circ} \mathrm{C}$ and, after washout of unbound material, were incubated on ice in the presence of 40 nM unlabeled NGF. "Acid stripping" was used to determine surface-bound NGF. Data are expressed as the amount of ${ }^{125}$ I-NGF associated with the cell surface at the designated time, relative to the amount associated with the surface at the initiation of the incubation with unlabeled ligand. $B$, Amounts of ${ }^{125} \mathrm{I}-\mathrm{NGF}$ internalized or associated with the surface of PC12, nnr5T1, and nnr5T14 cells after various times of incubation. Detcrmination of intcrnalized and surface-bound NGF was made as described in Materials and Methods. Briefly, replicate cultures were incubated with $\sim 210 \mathrm{pM}{ }^{125} \mathrm{I}-\mathrm{NGF}$ for the indicated times at $37^{\circ} \mathrm{C}$, washed free of unbound material, and assessed for surface-bound and internalized ${ }^{125}$ I-NGF by "acid stripping." Data represent the average of determinations on duplicate cultures. Variation between duplicates was $<10 \%$.

genes examined, thymosin $\beta 4$ is not expressed in PC12nnr5 cells, or in the lines derived by transfection with $t r k$, regardless of the presence or absence of NGF (Fig. $5 \mathrm{C}$ ).

Modulation of AChE activity by NGF is rescued in PC12nnr5 

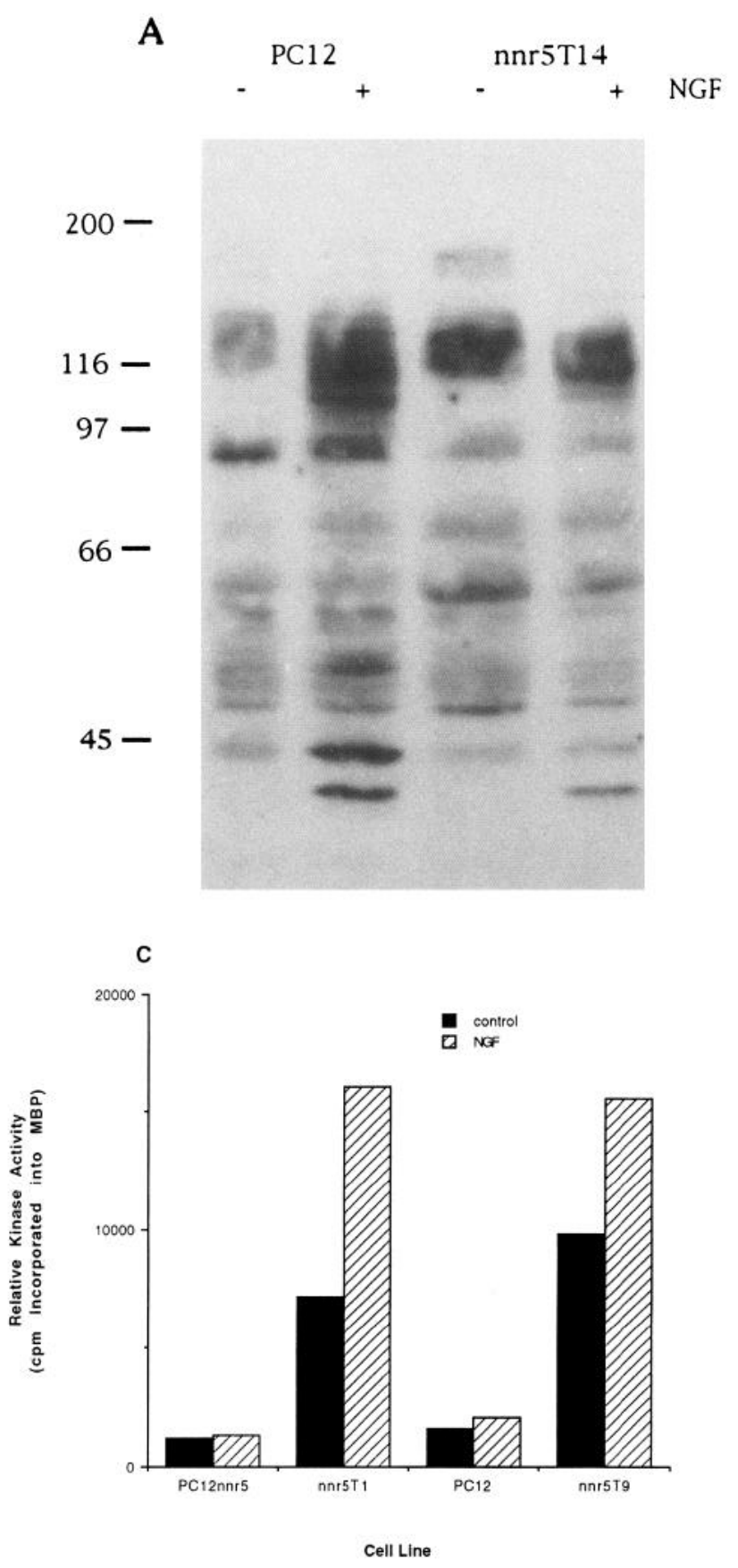

cell lines permanently expressing gp $140^{\text {protork }}$. The neuronal character of NGF-treated PC12 cells is not limited to neurite outgrowth and gene expression. This factor also modulates the expression and activity of enzymes involved in the synthesis and degradation of neurotransmitters (reviewed in Levi and Alemà, 1991). One such enzyme is AChE (Rieger et al., 1980; Greene and Rukenstein, 1981). Accordingly, AChE activity was measured in PC12, PC12nnr5, nnr5T1, and nnr5T14 cells treated with $100 \mathrm{ng} / \mathrm{ml} \mathrm{NGF}$ for $3 \mathrm{~d}$ and compared to activity measured in cells untreated with NGF. While AChE activity in PC12nnr5 and nnr5T1 cells was unaffected by NGF, PC12 and nnr5T14 cells exhibited a two- to sixfold increase in AChE activity in response to this factor (Fig. 6).

Expression of gp 140 protrk rescues NGF-dependent neurite out-

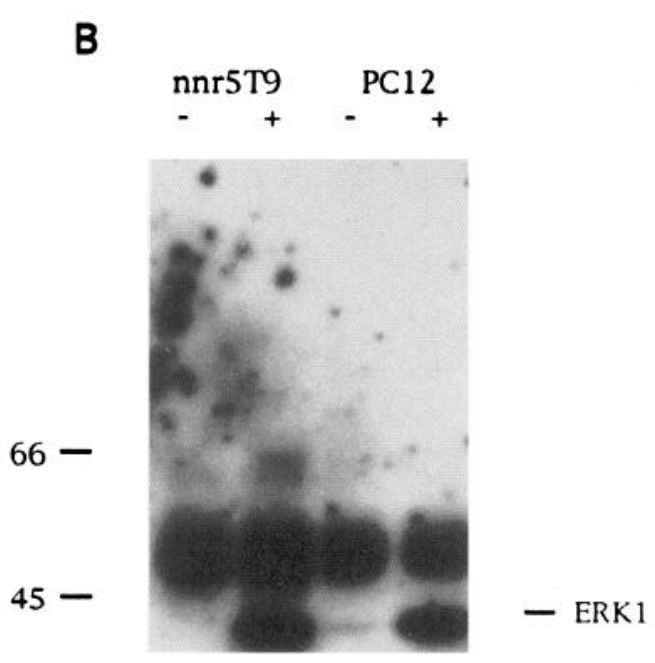

Figure 4. NGF-dependent tyrosine phosphorylations and association between gp140 prototrk and cytoplasmic kinases. $A, \mathrm{PC} 12$ and nnr5T14 cells, untreated (-) or treated for $5 \mathrm{~min}$ with $100 \mathrm{ng} / \mathrm{ml} \mathrm{NGF}(+)$, were lysed in isotonic buffer and soluble proteins were subjected to SDSPAGE, followed by Western blotting with anti-phosphotyrosine. Relative migration of molecular weight standards $\left(M_{r} \times 10^{-3}\right)$ is indicated. $B, \mathrm{PC} 12$ and nnr5T9 cells, treated with $(+)$ or without $(-)$ NGF, were lysed and immunoprecipitated with anti-Trk antiserum 43. After SDSPAGE, proteins were subjected to Western blotting analysis with antiERK antiserum X837 (Boulton and Cobb, 1991). Relative migration of molecular weight standards $\left(M_{r} \times 10^{-3}\right)$ is indicated. The position of ERK1 is also marked. $C$, PC12, PC12nnr5, nnr5T1, and nnr5T9 cells, untreated or treated with $100 \mathrm{ng} / \mathrm{ml} \mathrm{NGF}$ for $5 \mathrm{~min}$, were lysed and subjected to immunoprecipitation with anti-Trk antiserum 443 . Immune complexes were washed and assayed for in vitro kinase activity as described in Materials and Methods, using MBP as substrate. Relative kinase activity was determined by Cerenkov counting of MBP excised from an SDS-polyacrylamide gel.

growth and regeneration in transfected cell lines. The most obvious phenotypic effect of NGF on PC12 cells is neurite outgrowth. The initial elaboration of neurites by $\mathrm{PC} 12$ cells in response to NGF takes place over a time course of days (Greene and Tischler, 1976), while in contrast, the regeneration of neurites by NGF-pretreated cells occurs over a course of hours (Greene, 1977; Burstein and Greene, 1978). The initial rate of neurite outgrowth was measured in transfected cell lines. Each trk-expressing cell line, but not PC12nnr5 or nnr5T1 cells, exhibits NGF-dependent neurite outgrowth (Fig. $7 A$ ). In each case, the rate of appearance of neurites was increased in the Trkoverexpressing cell lines as compared to $\mathrm{PC} 12$ cells. The trktransfected cell lines were also able rapidly to regenerate neurites to an extent similar to PC12 cells (compare Fig. $7 B$ ). 


\begin{tabular}{lllllll}
\hline Table 1. & \multicolumn{7}{l}{ Regulation of late gene expression by NGF } \\
Cell line & $\begin{array}{l}\text { Periph- } \\
\text { erin }\end{array}$ & MAP1 & Transin & $\beta 4$ & NILE/L1 & p75 \\
\hline PC12 & 2.4 & 3 & $\infty$ & 2 & 4.2 & 1.8 \\
nnr5T14 & 2 & 3.3 & $\infty$ & - & 2.1 & 4.3 \\
\hline
\end{tabular}

Cell cultures were treated with or without $100 \mathrm{ng} / \mathrm{ml} \mathrm{NGF}$ for $7 \mathrm{~d}$. Total RNA was isolated and separated on a $1 \%$ agarose gel with $3.7 \%$ formaldehyde. After transfer to nitrocellulose, blots were probed with sequences specific to the indicated genes. Equal loading of RNA in each lane was verified by ethidium bromide staining. Numbers indicate fold induction by NGF in $7 \mathrm{~d}$. - indicates not detected. $\infty$ indicates that signal was detected only after NGF treatment.

gp140 protork expression restores $N G F$-dependent survival in serum-free medium in transfected cell lines. Another characteristic response of PC12 cells is the ability of NGF to promote their survival in serum-free medium. PC12 and PC12nnr cells die in serum-free medium, but the former are rescued by NGF (Greene, 1978; Green et al., 1986; Rukenstein et al., 1991). The capacity of the $t r k$-transfected cell lines to survive in serum-free medium was therefore assessed. NGF supported the survival of PC12, nnr5T8, and nnr5T14 cells in serum-free medium but was unable to do so for PC12nnr5 or nnr5T1 cells (Fig. 8). nnr5T9 cells showed spontaneous survival in serum-free medium, so assessment of NGF effects under these conditions was not informative (data not shown).

\section{Discussion}

We have used the PC12nnr5 cell line to examine the role of gp 140 prototrk in NGF-mediated neuronal responses and in NGF binding and uptake. PC12nnr5 cells were derived from parental PC12 cells by chemical mutagenesis and selected for lack of NGF-promoted neurite outgrowth and serum-free survival (Green et al., 1986). Work from a number of laboratories has confirmed that a variety of other NGF responses are absent from these cells, and that their capacities to bind and internalize NGF are altered (Green et al., 1986; Kasaian and Neet, 1990; Altin et al., 1991; Eveleth and Bradshaw, 1992). It has also been demonstrated that these cells do not express the gp $140^{\text {prototrk }}$ NGF receptor (Loeb et al., 1991). Consequently, three issues were considered in this work. Is Trk expression required for all of the many neuronal responses to NGF? Does this receptor play a role in "slow" NGF binding and in NGF internalization? Do PC12nnr5 cells possess additional defects in the NGF signaling pathway? To this end we generated and characterized three PC12nnr5 lines that are permanently transfected with a cDNA encoding human gp140 prototr. These lines have enabled us to examine a wide range of phenotypic responses not accessible in transiently transfected cells, and to do so in a neuronal cell type.

Trk and NGF responsiveness. We examined a wide range of NGF responses that varied with respect to their dependence on macromolecular synthesis, time and duration of expression, specificity for NGF, proximity to NGF binding in the signaling pathway, and sensitivity to purine analog protein kinase inhibitors. Without exception, every response examined is absent in the PC12nnr5 cells and is rescued by introduction of a cDNA

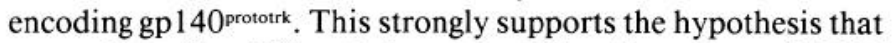
expression of $\mathrm{gp} 140^{\text {prototrk }}$ is required for all aspects of NGF

Figure 5. NGF-dependent gene expression. $A, \mathrm{PC} 12$ and nnr5T14 cells were treated for the indicated number of minutes with $100 \mathrm{ng} / \mathrm{ml} \mathrm{NGF}$

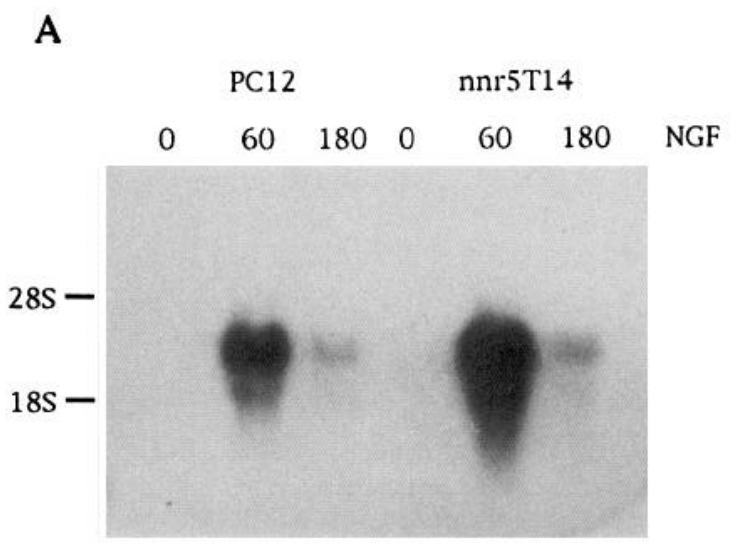

B

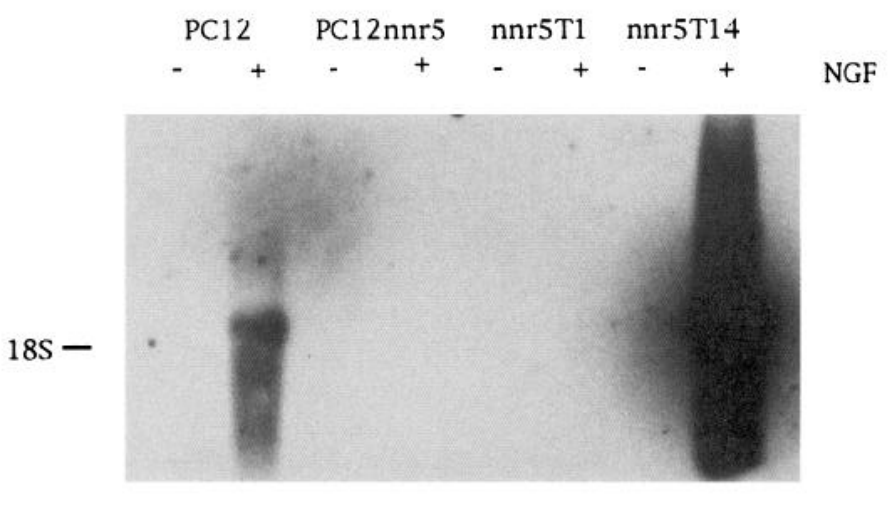

C

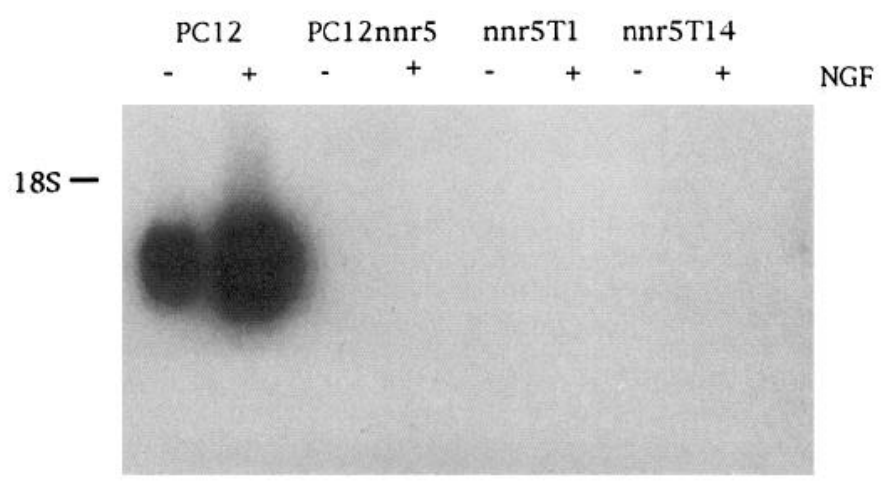

prior to isolation of total cellular RNA. Northern blotting analysis (20 $\mu \mathrm{g}$ RNA/lane) was performed with a probe specific for c-fos (Curran et al., 1982). The positions of the $18 \mathrm{~S}$ and $28 \mathrm{~S}$ rRNAs are indicated. $B$, Total cellular RNA was isolated from PC12, PC12nnr5, nnr5T1, and nnr5T14 cells, untreated (-) or treated for $7 \mathrm{~d}$ with $100 \mathrm{ng} / \mathrm{ml} \mathrm{NGF}$ $(+)$. Northern blotting $(20 \mu \mathrm{g} /$ lane $)$ was performed with a probe specific for transin (Matrisian et al., 1985). The position of the 18S rRNA is indicated. Blot is overexposed to emphasize the lack of signal in PC12nnr5 and nnr5T1 cells. $C$, RNA ( $20 \mu \mathrm{g} /$ lane) prepared as above was subjected to Northern blotting analysis with a probe specific for thymosin $\beta 4$ (Leonard et al., 1987). The position of the 18S rRNA is indicated. In each case, equal loading of RNA in each lane was verified by ethidium bromide staining. 


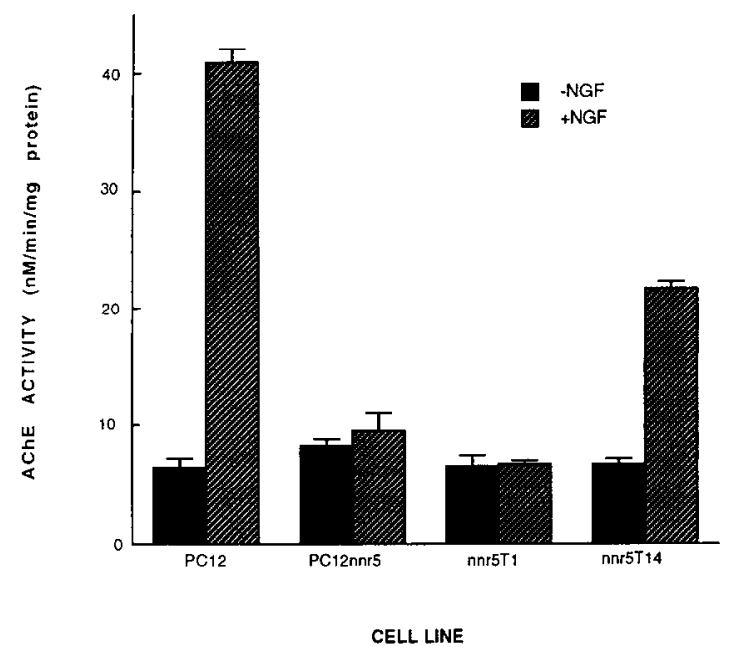

Figure 6. Induction of AChE activity. Cells were treated with or without $100 \mathrm{ng} / \mathrm{ml} \mathrm{NGF}$ for $5 \mathrm{~d}$ prior to assay for AChE activity as described in Materials and Methods. Data are presented as nanomoles of ACh hydrolyzed $/ \mathrm{min} / \mathrm{mg}$ protein and represent the mean $\pm \operatorname{SEM}(n=3)$.

responsiveness and that all responses to NGF are mediated by this receptor (either alone or in combination with p75). Thus, it does not appear necessary to invoke additional receptors that mediate portions of the NGF response.

Our results also address the possibility that $\mathrm{p} 75$ functions to transduce an NGF signal independently from gp $140^{\text {protork. We }}$ considerably extended the range of NGF actions previously assayed in PC12nnr5 cells, including regulation of a number of "late" genes. We confirmed that although these cells express p 75 they do not respond to NGF. Because all classes of response could be rescued by introduction of a single gene, it is exceedingly unlikely these cells possess additional defects that independently compromise p75-mediated signaling. We therefore suggest that $\mathrm{p} 75$ alone does not mediate functional responses to NGF in PC12 cells. This is consistent with the findings of Ibáñez et al. (1992) and Drinkwater et al. (1991) that mutant NGF molecules incapable of interacting with p 75 still mediate survival and neurite outgrowth in neuronal cultures.

Recently, p75 has been postulated to mediate signaling by glycosylphosphatidylinositol turnover in cochleovestibular ganglia (Represa et al., 1991). It will be of interest to determine whether this pathway exists in PC12 and PC12nnr5 cells. If such a pathway is stimulated in the absence of gp $140^{\text {prototrk }}$, this would indicate that this signaling mechanism is not required for the responses we considered or that it is involved in responses we did not assess.

Additional studies have suggested that $\mathrm{p} 75$ may mediate NGFenhanced expression of several surface glycoproteins in glial cells that appcar to lack gp $140^{\text {prototrk }}$ (Seilheimer and Schachner, 1987; Saad et al., 1991). We found here that NGF regulation of at least one of these, the NILE/L 1 glycoprotein, requires gp $140^{\text {prototrk. }}$ Thus, there may be a fundamental difference between neuronal and glial cells with respect to NGF signaling pathways, or glial cells may indeed express an NGF receptor in addition to $\mathrm{p} 75$.

$N G F$ binding and uptake. Because of the difficulties involving interpretation of experiments designed to detect "high" and "low" affinity NGF receptors in PC12 and PC12nnr cells (Green et al., 1986; Kasaian and Neet, 1990; Eveleth and Bradshaw, 1992), we chose to assess whether expression of gp $140^{\text {protork }}$
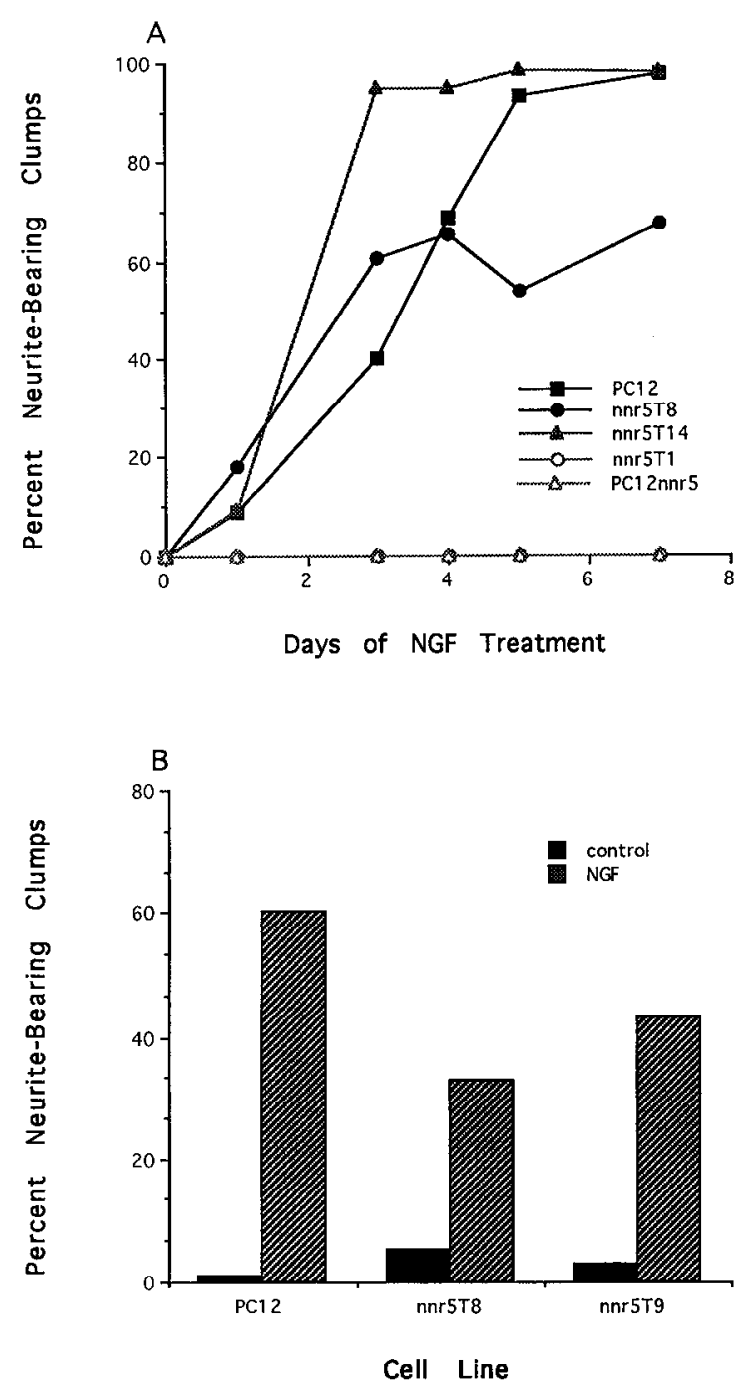

Figure 7. Neurite outgrowth and regeneration. $A, \mathrm{PC1} 2, \mathrm{PC1} 2 \mathrm{nnr} 5$, nnr5T1, and nnr5T 14 cells were treated with $100 \mathrm{ng} / \mathrm{ml} \mathrm{NGF}$, and the proportions of neurite-bearing cell clumps were counted each day as described in Materials and Methods. B, PC12, nnr5T8, and nnr5T14 cells were treated with NGF for $7 \mathrm{~d}$. Cells were then triturated to remove neurites and replated in fresh medium, with or without $100 \mathrm{ng} / \mathrm{ml} \mathrm{NGF}$. After $18 \mathrm{hr}$, the percentage of neurite-bearing cell clumps was determined as described in Materials and Methods.

would affect the dissociation rate of iodinated NGF from the cell surface. We confirmed past observations that at low concentrations of external NGF, more than $80 \%$ of the surface binding to wild-type PC12 cells appeared to be to "slow" receptors. In contrast, $45-65 \%$ of surface-bound NGF was rapidly released from the surface of PC12nnr5 cells. Transfection with trk reversed this situation such that most of the binding appeared to be to "slow" receptors. These observations indicate that gp 140 protork restores normal levels of "slow" receptor binding and thus that this molecule plays an important role in "slow" receptor expression. This is consistent with recent findings that gp 140 prototr expressed in fibroblasts exhibits the characteristics of "slow" NGF receptors (Meakin et al., 1992).

The significance of an apparent fraction of "slow" receptors on PCl2nnr5 cells in the absence of gp $140^{\text {protork }}$ is unclear. This does not appear to be due to internalized NGF; past work has demonstrated that the acid-stripping technique we used here 
successfully distinguishes externally bound from internalized NGF (Bernd and Greene, 1984). One possibility is that $\mathrm{p} 75$ can generate at least some "slow" receptor binding when expressed in the absence of gp140 prorork. Kahle and Hertel (1992) demonstrated incomplete dissociation of NGF from the surfaces of glial cells expressing only p 75 when the initial binding was performed at $37^{\circ} \mathrm{C}$, as was ours. An alternative is that a portion of the p75-bound NGF is in a "sequestered" state that is not truly internalized, but that exchanges slowly with free NGF in the medium (Eveleth and Bradshaw, 1988). In either case, the presence of $\mathrm{gpl} 40^{\text {protork }}$ appears to affect the proportion of bound NGF that undergoes this "slow" dissociation.

A second parameter we analyzed is internalization of NGF. Neurons appear to take up NGF with high efficiency and to transport it to their cell bodies (Yankner and Shooter, 1979; Korsching and Thoenen, 1983a; Palmetier et al., 1984). Interference with this transport abolishes the actions of target-derived NGF (Chen et al., 1977; Johnson, 1978). This has led to the suggestion that internalization and retrograde transport are important components of the NGF mechanism (Korsching and Thoenen, 1983b). PC12 cells show efficient uptake of low concentrations of the factor such that by $1 \mathrm{hr}$ of incubation, the I/S NGF ratio is 3-4 (Green et al., 1986; present results). In contrast, PC12nnr 5 cells take up NGF with relatively low efficiency such that the I/S ratio after $1 \mathrm{hr}$ is approximately 1 (Green et al., 1986; present results). We observed that reintroduction of gp 140 protork yielded wild-type uptake characteristics. This indicates that the Trk receptor plays a necessary role in efficient NGF internalization. Our data do not, however, distinguish whether p75, though not sufficient, is also required for such uptake

PC12nnr5 cells as models for analyzing functional domains of Trk receptors. If the only aspect of the NGF signaling mechanism that is aberrant in PC12nnr5 cells is the absence of trk expression, then this cell system should provide a powerful tool for analyzing functional domains of gp 140 proverk and other Trk receptors. Evaluation of this issue was among the reasons we tested our PC12nnr5 transfectants for a wide variety of responses and signaling pathways as well as for NGF dissociation and internalization. Our findings support the adequacy of this cell system for functional studies of trk domains.

One difference detected here between $\mathrm{PC} 12$ cells and $\mathrm{PC} 12$ nnr5-derived lines is the absence of thymosin $\beta 4$ expression in the latter. This polypeptide binds $\mathrm{G}$-actin, preventing microfilament assembly (Weber et al., 1992), and overexpression of thymosin $\beta 4$ has been shown to regulate actin filament dynamics in living cells (Sanders et al., 1992). Because actin dynamics are likely to be involved in process outgrowth (Lankford and Letourneau, 1989; Sobue and Kanda, 1989; Paves et al., 1990), and because thymosin $\beta 4$ expression is regulated by NGF (Leonard et al., 1987), a functional role for this protein in neuronal differentiation might be envisioned. However, despite their lack of thymosin $\beta 4$ expression, nnr5T 14 cells extend neurites in response to NGF with no obvious difference from those in wild-type PC12 cells. Thus, it appears that thymosin $\beta 4$ expression is not required for neurite outgrowth. We cannot exclude the possibility that another protein, perhaps the closely related thymosin $\beta 10$ (Lin and Morrison-Bogorad, 1991), substitutes for thymosin $\beta 4$ in these cells.

In summary, our findings indicate that expression of gp $140^{\text {protork }}$ is required for many, if not all, responses of neuronal cells to $\mathrm{NGF}$, that gp $140^{\text {prototrk }}$ plays a role in "slow" NGF binding and

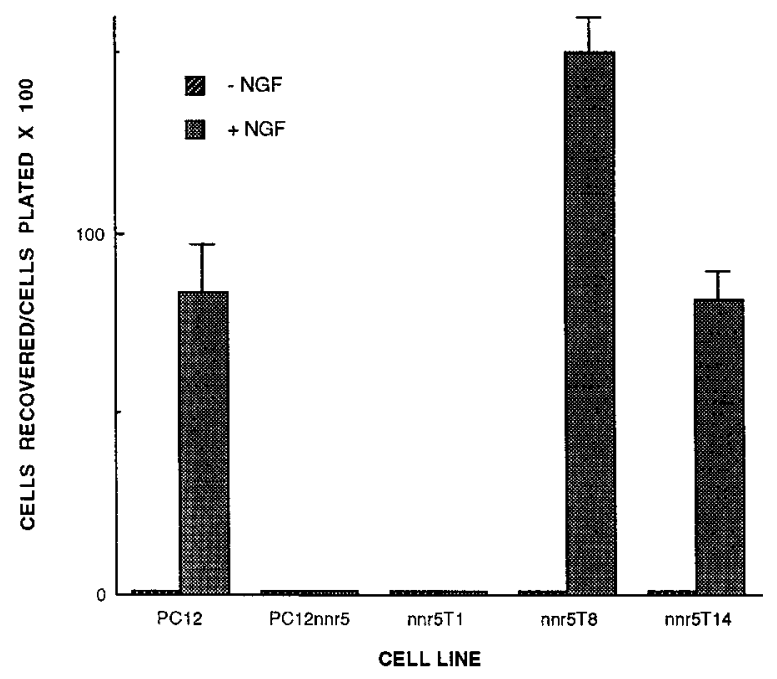

Figure 8. Survival in serum-free medium. PC12, PC12nnr5, nnr5T1, nnr5T8, and nnr5T14 cells were washed free of serum and incubated in the presence or absence of $50 \mathrm{ng} / \mathrm{ml} \mathrm{NGF}$ for $7 \mathrm{~d}$. After this period, the number of surviving cells was determined in each culture. Results are expressed relative to number of cells initially plated $\left(10^{5}\right)$ and represent means \pm SEM $(n=3)$.

efficient internalization of the factor, and that the PC12nnr5 cell line is a valid model for functional studies of Trk neurotrophin receptors.

\section{References}

Altin IG, Kujubu DA, Raffioni S, Eveleth DD, Herschman HR, Bradshaw RA (1991) Differential induction of primary-response (TIS) genes in $\mathrm{PC} 2$ pheochromocytoma cells and the unresponsive variant PC12nnr5. J Biol Chem 266:5401-5406.

Barde Y-A (1989) Trophic factors and neuronal survival. Neuron 2:1525-1534.

Batistatou A, Volonté C, Greene LA (1992) Nerve growth factor employs multiple pathways to induce primary response genes in $\mathrm{PC} 12$ cells. Mol Biol Cell 3:363-371.

Bernd P, Greene LA (1984) Association of ${ }^{125}$ I-nerve growth factor with $\mathrm{PC} 12$ pheochromocytoma cells: evidence for internalization via high-affinity receptors only and for long-term regulation by nerve growth factor of both high- and low-affinity receptors. J Biol Chem 259:15509-15516.

Bothwell M (1991) Keeping track of neurotrophin receptors. Cell 65: 915-918.

Boulton TG, Cobb MH (1991) Identification of multiple extracellular signal-regulated kinases (ERKs) with antipeptide antibodies. Cell Regulation 2:357-371.

Boulton TG, Nye SH, Robbins DJ, Ip NY, Radziejewska E, Morgenbesser SD, DePinho RA, Panayotatos N, Cobb M, Yancopoulos GD (1991) ERKs: a family of protein-serine/threonine kinases that are activated and tyrosine phosphorylated in response to insulin and NGF. Cell 65:663-675.

Burstein DE, Greene LA (1978) Evidence for RNA synthesis-dependent and -independent pathways in stimulation of neurite outgrowth by nerve growth factor. Proc Natl Acad Sci USA 75:6059-6063.

Calissano P, Shelanski ML (1980) Interaction of NGF with pheochromocytoma cells: evidence for tight binding and sequestration. Neuroscience 5:1033-1039.

Cattaneo E, McKay R (1990) Proliferation and differentiation of neuronal stem cells regulated by nerve growth factor. Nature $347: 762-$ 765.

Chao MV, Bothwell MA, Ross AH, Koprowski H, Lanahan AA, Buck CR, Sehgal A (1986) Gene transfer and molecular cloning of human NGF receptor. Science 232:518-521.

Chen MGM, Chen JS, Calissano P, Levi-Montalcini R (1977) Nerve growth factor prevents vinblastine destructive effects on sympathetic ganglia in newborn mice. Proc Natl Acad Sci USA 74:5559-5563. 
Chomczynski P, Sacchi N (1987) Single-step method of RNA isolation by acid guanidinium thiocyanate-phenol-chloroform extraction. Anal Biochem 162:156-159.

Cordon-Cardo C, Tapley P, Jing S, Nanduri V, O'Rourke E, Lamballe F, Kovary K, Klein R, Jones KR, Reichardt LF, Barbacid M (1991) The trk tyrosine protein kinase mediates the mitogenic properties of nerve growth factor and neurotrophin-3. Cell 66:173-183.

Curran T, Peters G, Van Beveran C, Teich NM, Verma I (1982) FBJ murine osteosarcoma virus.

Drinkwater CC, Suter U, Angst C, Shooter EM (1991) Mutation of tryptophan-2 1 in mouse nerve growth factor (NGF) affects binding to the fast NGF receptor but not induction of neurites on PC12 cells. Proc K Soc Lond [Biol] 246:307-313.

Eveleth DD, Bradshaw RA (1988) Internalization and cycling of nerve growth factor in PC12 cells: interconversion of type II (fast) and type I (slow) nerve growth factor receptors. Neuron 1:929-936.

Eveleth DD, Bradshaw RA (1992) Nerve growth factor nonresponsive pheochromocytoma cells: altered internalization results in signaling dysfunction. J Cell Biol 117:291-299.

Green SH, Greene LA (1986) A single $M_{r}=103,000{ }^{125}$ I- $\beta$-nerve growth factor-affinity-labeled species represents both the low and high affinity forms of the nerve growth factor receptor. J Biol Chem 261: $15316-15326$.

Green SH, Rydel RE, Connolly JL, Greene LA (1986) PC1 2 cell mutants that possess low- but not high affinity nerve growth factor receptors. J Cell Biol 102:830-843.

Greenberg ME, Greene LA, Ziff EB (1985) Nerve growth factor and epidermal growth factor induce rapid transient changes in proto-oncogene transcription in PC12 cells. J Biol Chem 260:14101-14110.

Greene LA (1977) A quantitative bioassay for nerve growth factor (NGF) activity employing a clonal pheochromocytoma cell line. Brain Res 133:350-353.

Greene LA (1978) Nerve growth factor prevents the death and stimulates neuronal differentiation of clonal PC12 pheochromocytoma cells in scrum-frce mcdium. J Ccll Biol 78:747-755.

Greene LA, Rukenstein A (1981) Regulation of acetyl cholinesterase activity by nerve growth factor: role of transcription and dissociation from effects on proliferation and neurite outgrowth. J Biol Chem 256: 6363-6367.

Greene LA, Tischler AS (1976) Establishment of a noradrenergic clonal line of rat adrenal pheochromocytoma cells which respond to nerve growth factor. Proc Natl Acad Sci USA 73:2424-2428.

Greene LA, Sobeih MM, Teng KK (1991) Methodologies for the culture and experimental use of the $\mathrm{PC} 12$ rat pheochromocytoma cell line. In: Culturing nerve cells (Banker G, Goslin K, eds), pp 207-226. Cambridge, MA: MIT Press.

Hempstead BL, Rabin SJ, Kaplan L, Reid S, Parada LF, Kaplan DR (1992) Overexpression of the $t r k$ tyrosine kinase rapidly accelerates nerve growth factor-induced differentiation. Neuron 9:883-896.

Ibáñez CF, Ebendal T, Barbany G, Murray-Rust J, Blundell TL, Persson H (1992) Disruption of the low affinity receptor-binding site in NGF allows neuronal survival and differentiation by binding to the $t r k$ gene product. Cell 69:329-341.

Johnson EM (1978) Destruction of the sympathetic nervous system in neonatal rats and hamsters by vinblastine: prevention by concomitant administration of nerve growth factor. Brain Res 141:105-118.

Johnson EM, Taniuchi M, Clark HB, Springer JE, Koh S, Tayrien MW, Loy R (1987) Demonstration of the retrograde transport of nerve growth factor receptor in the peripheral and central nervous system. J Ncurosci 7:923-929.

Kahle P, Hertel C (1992) Nerve growth factor (NGF) receptor on rat glial cell lines: evidence for NGF internalization via p7 $5^{\text {NGFR }}$. J Biol Chem 267:13917-13923.

Kaplan DR, Hempstead BL, Martin-Zanca D, Chao MV, Parada LF (1991a) The trk proto-oncogene product: a signal transducing receptor for nerve growth factor. Science 252:554-558.

Kaplan DR, Martin-Zanca D, Parada LF (1991b) Tyrosine phosphorylation and tyrosine kinase activity of the trk proto-oncogene product induced by NGF. Nature 350:158-160.

Kasaian MT, Neet KE (1990) A comparison of nerve growth factor binding protocols with native and mutant PC12 cells. Neurochem Res 15:1167-1174.

Klein R, Jing S, Nanduri V, O'Rourke E, Barbacid M (1991) The trk proto-oncogene encodes a receptor for nerve growth factor. Cell 65:189-197.
Korsching S, Thoenen H (1983a) Quantitative demonstration of retrograde transport of endogenous nerve growth factor. Neurosci Lett $39: 1-4$.

Korsching S, Thoenen H (1983b) Nerve growth factor in sympathetic ganglia and corresponding target organs of the rat: correlation with density of sympathetic innervation. Proc Natl Acad Sci USA 80: 3513-3516.

Kujubu DA, Lim RW, Varnum BC, Herschman HR (1987) Induction of transiently expressed genes in PC12 pheochromocytoma cells. Oncogene 1:257-262.

Laemmli UK (1970) Cleavage of structural protein during the assembly of the head of the bacteriophage. Nature 227:680-685.

Landreth GE, Shooter EM (1980) Nerve growth factor receptors on PC1 2 cells: ligand-induced conversion from low- to high-affinity states. Proc Natl Acad Sci USA 77:4751-4755.

Lankford KL, Letourneau PC (1989) Evidence that calcium may control neurite outgrowth by regulating the stability of actin filaments. J Cell Biol 109:1229-1243.

Leonard DGB, Ziff EB, Greene LA (1987) Identification and characterization of mRNAs regulated by nerve growth factor in $\mathrm{PCl} 2$ cells. Mol Cell Biol 7:3156-3167.

Leonard DGB, Gorham JD, Cole P, Greene LA, Ziff EB (1988) A nerve growth factor-regulated messenger RNA encodes a new intermediate filament protein. J Cell Biol 106:181-193.

Levi A, Alemà S (1991) The mechanism of action of nerve growth factor. Annu Rev Pharmacol Toxicol 31:205-228.

Levi A, Schechter Y, Neufeld EJ, Schlessinger J (1980) Mobility, clustering, and transport of nerve growth factor in embryonal sensory cells and in a sympathetic neuronal cell line. Proc Natl Acad Sci USA 77:3469-3473.

Levi A, Biocca S, Cattaneo A, Calissano P (1988) The mode of action of nerve growth factor in PC12 cells. Mol Neurobiol 2:201-226.

Levi-Montalcini $\mathrm{R}$ (1987) The nerve growth factor 35 years later. Science 237:1154-1162.

Lewis SA, Sherline P, Cowan NJ (1986) A cloned cDNA encoding MAP1 detects a single copy gene in mouse and a brain-abundant mRNA whose level decreases during development. J Cell Biol 102: 2106-2114.

Lin SC, Morrison-Bogorad M (1991) Cloning and characterization of a testis-specific thymosin beta 10 cDNA: expression in post-meiotic male germ cells. J Biol Chem 266:23347-23353.

Loeb DM, Maragos J, Martin-Zanca D, Chao MV, Parada LF, Greene LA (1991) The $t r k$ proto-oncogene rescues NGF responsiveness in mutant NGF-nonresponsive PC 12 cell lines. Cell 66:961-966.

Loeb DM, Tsao H, Cobb M, Greene LA (1992) NGF and other factors induce the association of ERK 1 and the NGF receptor, gp $140^{\text {protork. }}$ Neuron 9:1053-1065.

Machida CM, Rodland KD, Matrisian L, Magun BE, Ciment G (1989) NGF induction of the gene encoding the protease transin accompanies neuronal differentiation in PC12 cells. Neuron 2:1587-1596.

Maher P (1988) Nerve growth factor induces protein-tyrosine phosphorylation. Proc Natl Acad Sci USA 85:6788-6791.

Maher P (1989) Role of protein tyrosine phosphorylation in the NGF response. J Neurosci Res 24:29-37.

Martinez HJ, Dreyfus CF, Jonakait GM, Black IB (1985) Nerve growth factor promotes cholinergic development in brain atrial cultures. Proc Natl Acad Sci USA 82:7777-7781.

Martin-Zanca D, Oskam R, Mitra G, Copeland T, Barbacid M (1989) Molecular and biochemical characterization of the human $t r k$ protooncogene. Mol Cell Biol 9:24-33.

Matrisian LM, Glaichenhaus N, Gesnel MC, Breathnach R (1985) Epidermal growth factor and oncogenes induce transcription of the same cellular mRNA in rat fibroblasts. EMBO J 4:1435-1440.

Meakin SO, Shooter EM (1992) The nerve growth factor family of receptors. Trends Neurosci 15:323-331.

Meakin SO, Suter U, Drinkwater CC, Welcher AA, Shooter EM (1992) The rat trk protooncogene product exhibits properties characteristic of the slow nerve growth factor. Proc Natl Acad Sci USA 89:23742378.

Middlemas DS, Lindberg RA, Hunter T (1991) trkB, a neural receptor protein-tyrosine kinase: evidence for a full-length and two truncated receptors. Mol Cell Biol 11:143-153.

Milbrandt J (1986) Nerve growth factor rapidly induces c-fos mRNA in PC12 rat pheochromocytoma cells. Proc Natl Acad Sci USA 83: $4789-4793$. 
Milbrandt J (1987) A nerve growth factor-induced gene encodes a possible transcriptional regulatory factor. Science 238:797-799.

Milbrandt J (1988) Nerve growth factor induces a gene homologous to the glucocorticoid receptor gene. Neuron 1:183-188.

Miller FD, Mathew TC, Toma JG (1991) Regulation of nerve growth factor receptor gene expression by nerve growth factor in the developing peripheral nervous system. J Cell Biol 112:303-312.

Mobley WC, Schenker A, Shooter EM (1976) Characterization and isolation of proteolytically modified nerve growth factor. Biochemistry 15:5543-5552.

Nebreda AR, Martin-Zanca D, Kaplan DR, Parada LF, Santos E (1991) Induction by NGF of meiotic maturation of Xenopus oocytes expressing the trk proto-oncogene product. Science 252:558-561.

Palmetier MA, Hartman BK, Johnson EM (1984) Demonstration of retrogradely transported endogenous nerve growth factor in axons of sympathetic neurons. J Neurosci 4:751-756.

Paves H, Neuman T, Metsis M, Saarma M (1990) Nerve growth factor-induced rapid reorganization of microfilaments in PC12 cells: possible roles of different second messenger systems. Exp Cell Res 186:218-226.

Radeke MJ, Misko TP, Hsu C, Herzenberg LA, Shooter EM (1987) Gene transfer and molecular cloning of the rat nerve growth factor receptor. Nature 325:593-597.

Represa J, Avila MA, Miner C, Giraldez F, Romero G, Clemente R, Mato JM, Valera-Nieto I (1991) Glycosyl-phosphatidylinositol/inositol phosphoglycan: a signaling system for the low-affinity nerve growth factor receptor. Proc Natl Acad Sci USA 88:8016-8019.

Rieger F, Shelanski ML, Greene LA (1980) The effect of nerve growth factor on acetyl cholinesterase and its multiple forms in cultures of rat $\mathrm{PC} 12$ pheochromocytoma cells: increased total specific activity and appearance of the 16S molecular form. Dev Biol 76:238-243.

Ruit KG, Osborne PA, Schmidt RE, Johnson EM, Snider WD (1990) Nerve growth factor regulates sympathetic ganglion cell morphology and survival in the adult mouse. J Neurosci 10:2412-2419.

Rukenstein A, Rydel RE, Greene LA (1991) Multiple agents rescue PC12 cells from serum-free cell death by translation- and transcription-independent mechanisms. J Neurosci 11:2552-2563.

Saad B, Constam DB, Ortmann R, Moos M, Fontana A, Schachner M (1991) Astrocyte-derived TGF- $\beta 2$ and NGF differentially regulate neural recognition molecule expression by cultured astrocytes. J Cell Biol 1 15:473-484.

Sajovic P, Kouvelas E, Trenkner E (1986) Probable identity of NILE glycoprotein and the high-molecular-weight component of the L1 antigen. J Neurochem 47:541-546.

Salton SR, Richter-Landsberg C, Greene LA, Shelanski ML (1983) Nerve growth factor-inducible large external (NILE) glycoprotein: studies of a central and peripheral neuronal marker. J Neurosci 3:441454.

Sanders MC, Goldstein AL, Wang YL (1992) Thymosin beta 4 (Fx peptide) is a potent regulator of actin polymerization in living cells. Proc Natl Acad Sci USA 89:4678-4682.

Schechter AL, Bothwell MA (1981) Nerve growth factor receptors on PC1 2 cells: evidence for two receptor classes with differing cytoskeletal association. Cell 24:867-874.

Seilheimer B, Schachner M (1987) Regulation of neural cell adhesion molecule expression on cultured mouse schwann cells by nerve growth factor. EMBO J 6:1611-1616

Sobue K, Kanda K (1989) Alpha-actinins, calspectin (brain spectrin or fodrin), and actin participate in adhesion and movement of growth concs. Neuron 3:311-319.

Sutter A, Riopelle RJ, Harris-Warrick RM, Shooter EM (1979) Nerve growth factor receptors. J Biol Chem 254:5972-5982.

Vale RD, Shooter EM (1985) Assaying binding of nerve growth factor to cell surface receptors. Methods Enzymol 109:21-39.

Volonté C, Rukenstein A, Loeb DM, Greene LA (1989) Differential inhibition of nerve growth factor responses by purine analogues: correlation with inhibition of a nerve growth factor-activated protein kinase. J Cell Biol 109:2395-2403.

Volonté C, Loeb DH, Greene LA (1993) A purine-analog-sensitive protein kinase activity associates with Trk NGF receptors. J Neurochem, in press.

Weber A, Nachmias VT, Pennise CR, Pring M, Safer D (1992) Interaction of thymosin beta 4 with muscle and platelet actin: implications for actin sequestration in resting platelets. Biochemistry 31 6179-6185.

Wu BY, Fodor EJB, Edwards RH, Rutter WJ (1989) Nerve growth factor induces the proto-oncogene c-jun in PCI 2 cells. J Biol Chem 264:9000-9003.

Yankner BA, Shooter EM (1979) Nerve growth factor in the nucleus: interaction with receptors on the nuclear membrane. Proc Natl Acad Sci USA 76:1269-1273.

Zinn K, Keller A, Whittemore LA, Maniatis T (1988) 2-Aminopurine selectively inhibits the induction of $\gamma$-interferon, c-fos and c-myc gene expression. Science 240:210-213. 